\title{
Efektivitas Hukum Pelestarian Bangunan Dan Lingkungan Cagar Budaya Di Kota Denpasar
}

\author{
I Putu Sastra Wibawa dan Mahrus Ali \\ Fakultas Hukum Universitas Hindu Indonesia Denpasar Indonesia \\ Jln. Sangalangit, Tembau, Penatih, Denpasar, Indonesia 80238 \\ Fakultas Hukum Universitas Islam Indonesia Yogyakarta Indonesia \\ Jln. Tamansiswa No. 158 Yogyakarta Indonesia \\ sastra@unhi.ac.id; mahrus_ali@uii.ac.id
}

Received: 18 Juni 2020; Accepted: 1 Desember 2020; Published: 15 Desember 2020

https:/ / doi.org/10.20885/iustum.vol27.iss3.art9

\begin{abstract}
The Regional Regulation on Cultural Heritage of Denpasar City has been in effect for 5 years, it is very important to assess its effectiveness. There are two problems raised in this study. First, how effective is the Denpasar City Cultural Heritage Regional Regulation? Second, what is the strategy to achieve the effectiveness of the Denpasar City Cultural Heritage Regional Regulation? Data analysis was carried out both from primary data from the results of interview data, and analysis of secondary data in the form of primary and secondary legal materials. Therefore, this research can be called a research that uses mixed methods or is categorized as a socio-legal research. The results of the study conclude, firstly, regarding the effectiveness of the Regional Regulation on Cultural Heritage of Denpasar City, it can be reviewed from three sides, namely the role of regional officials, the rule of law, and legal awareness of the community. Second, the Regional Regulation on Cultural Heritage of Denpasar City is still not effective in regulating and implementing it in supporting the preservation and management of cultural heritage in Denpasar City. To achieve the legal effectiveness of the Denpasar City Cultural Heritage Regional Regulation, several strategies can be pursued, among others, the legal aspect strategy, the institutional aspect strategy, the physical aspect strategy and the financial aspect strategy.
\end{abstract}

Key Words: Cultural heritage; effectivity; regional regulation

\section{Abstrak}

Perda Cagar Budaya Kota Denpasar telah berlaku 5 tahun, sangat penting untuk dikaji efektivitasnya. Terdapat dua permalasahan yang diangkat dalam penelitian ini. Pertama, bagaimana efektivitas Perda Cagar Budaya Kota Denpasar? Kedua, bagaimana strategi untuk mencapai efektivitas Perda Cagar Budaya Kota Denpasar? Analisis data dilakukan baik dari data primer dari hasil data wawancara, maupun analisis terhadap data sekunder berupa bahan hukum primer dan bahan hukum sekunder. Karenanya, penelitian ini dapat disebut sebagai penelitian yang menggunakan metode campuran atau dikategorikan dalam penelitian sosio-legal. Hasil penelitian menyimpulkan, pertama, terkait efektivitas Perda Cagar Budaya Kota Denpasar dapat di tinjau dari tiga sisi, yakni peran aparatur daerah, aturan hukum, dan kesadaran hukum masyarakat. Kedua, Perda Cagar Budaya Kota Denpasar masih belum efektif pada pengaturan dan implementasinya dalam menunjang pelestarian dan pengelolaan cagar budaya di Kota Denpasar. Untuk mencapai efektivitas hukum Perda Cagar Budaya Kota Denpasar dapat ditempuh dengan beberapa strategi, antara lain, strategi aspek legal, strategi aspek kelembagaan, strategi aspek fisik dan strategi aspek keuangan

Kata-kata Kunci: Efektivitas; peraturan daerah; cagar budaya 


\section{Pendahuluan}

Kota Denpasar sebagai ibukota Provinsi Bali telah melabelkan statusnya menjadi Kota Budaya. Setidaknya, terdapat beberapa langkah yang telah dilakukan Pemerintah Kota Denpasar untuk melegitimasi statusnya tersebut. Pada 2010, Kota Denpasar bergabung sebagai anggota Jaringan Kota Pusaka Indonesia. Selanjutnya, pada tahun berikutnya, 2011, Kota Denpasar bergabung sebagai anggota Badan Pelestari Pusaka Indonesia. Secara internasional, dua tahun selanjutnya, 2013, Kota Denpasar bergabung sebagai bagian dari Kota Pusaka Internasional. Dengan semua potensi budaya yang dimiliki, pada 2014, Pemerintah Kota Denpasar masuk sebagai bagian dari Kota Kreatif UNESCO, secara khusus sebagai Kota kreatif kerajinan dan seni rakyat. Manfaatnya, produk-produk lokal di Kota Denpasar dapat dikembangkan dan dipromosikan di jaringan bertaraf internasional di era global. ${ }^{1}$ Walaupun Kota Denpasar telah bergabung menjadi anggota jejaring internasional terkait Kota Pusaka, namun nilai-nilai kearifan lokal yang ada harus tetap dipertahankan. Pembangunan di Denpasar tidak boleh terlepas dari ideologi tri hita karana, sebagai salah satu kearifan lokal. ${ }^{2}$ Tri hita karanamerupakan filtrasi dalam proses pembangunan di Kota Denpasar. ${ }^{3}$ Nilai tri hita karana secara garis besar memuat hubungan harmonis yang tercipta dari harmonisnya hubungan manusia dengan Tuhan, sesama manusia, dan alam sekitarnya.

Kota Pusaka Denpasar memiliki peninggalan-peninggalan sejarah. Didalamnya terkandung pusaka sejarah berwujud (tangible) dan tidak berwujud (intangible). ${ }^{4}$ Kekayaan warisan budaya di Kota Denpasar termasuk tempat suci (pura), puri (kerajaan), pasar tradisional, alun-alun, arsitektur kolonial, ruang

${ }^{1}$ Febianti Febianti, "Memperkuat Citra Pariwisata Budaya: Denpasar Sebagai Nominasi Jaringan Kota Kreatif Unesco", Jurnal Master Pariwisata (JUMPA), Vol. 1 No. 2, Juni 2015, hlm. 5. <https://doi.org/10.24843/jumpa.2015.v01.i02.p05>.

${ }^{2}$ Anak Agung Gde Bagus Udayana, "Marginalisasi Ideologi Tri Hita Karana Pada Media Promosi Pariwisata Budaya Di Bali", Mudra Jurnal Seni Budaya, Vol. 32 No. 1, Juni 2017, hlm. 4. <https://doi.org/10.31091/mudra.v32i1.4>.

3I Putu Arya Mulyawan, Dewa Gede Wirama, dan I Dewa Nyoman Badera, "Budaya Tri Hita Karana Sebagai Pemoderasi Pengaruh Prinsip Good Corporate Governance Pada Kinerja Lembaga Perkreditan Desa Di Kota Denpasar", E-Jurnal Ekonomi Dan Bisnis Universitas Udayana, Vol. 6 No. 8, Agustus 2017, hlm. 10. <https://doi.org/10.24843/eeb.2017.v06.108.p10>.

${ }^{4}$ lury Sevita Yusiana, "Konsep Interpretasi Guna Melestarikan Tapak Sejarah Di Pecinan Jalan Gajah Mada, Denpasar", Jurnal Arsitektur Lansekap, Vol. 2 No. 2, Oktober 2016, hlm. 165. <https://doi.org/10.24843/jal.2016.v02.i02.p07>. 
terbuka hijau, koridor sungai, dan lingkungan sekitarnya untuk menuju transformasi Kota Denpasar menjadi Kota Budaya. ${ }^{5}$

Salah satu hal terpenting yang harus diperhatikan oleh Kota Denpasar untuk bertransformasi menjadi Denpasar Kota Budaya yakni adanya perlindungan terhadap cagar budaya yang ada di Kota Denpasar. Pada Rencana Pembangunan Jangka Menengah Daerah (RPJMD) Kota Denpasar Tahun 20162021, dicantumkan cagar budaya yang ada di Kota Denpasar yakni Pura Jumeneng (Kelurahan Sanur), Pura Maospahit (Kelurahan Pemecutan), Museum Bali (Kelurahan Dangin Puri), Pura Maospahit (Kelurahan Tonja), Pura Meja Batu (Kelurahan Tonja), Pura Presada (Kelurahan Tonja), Pura Batu Pesiraman (Kelurahan Tonja), Pura Segara (Desa Sanur), Pura Kaleran (Kelurahan Pemecutan), Pura Blanjong (Desa Sanur Kauh), Pura Sakenan (Kelurahan Serangan), Pura Sungsungan Wadon (Kelurahan Serangan), Pura Cemara (Kelurahan Serangan), Pura Rambut Siwi (Kelurahan Tonja, dan Pura Majelangu (Kelurahan Pemecutan). Selain itu, dalam RPJMD Kota Denpasar Tahun 20162021, tercatat bahwa terdapat benda cagar budaya sebanyak 93 benda, bangunan cagar budaya sebanyak 18 bangunan, dan struktur cagar budaya sebanyak 22 struktur. Pada 2018, telah terdata 300 buah cagar budaya baik berupa bangunan, struktur, situs, dan kawasan cagar budaya. ${ }^{6}$

Peraturan Daerah Kota Denpasar Nomor 12 Tahun 2015 tentang Pengelolaan Cagar Budaya (Perda Cagar Budaya Kota Denpasar) dibentuk untuk menjaga cagar budaya di Kota Denpasar terdapat secara normatif. Namun, Perda Cagar Budaya Kota Denpasar mengandung beberapa kelemahan secara normatif, antara lain: belum adanya aturan pelaksanaan perda terkait dengan pemberian kompensasi, insentif serta mekanisme perizinan cagar budaya (norma kosong) serta secara empiris perda cagar budaya tersebut belum berjalan secara maksimal. Pengaturan secara maksimaltersebut penting karena cagar budaya memiliki nilai penting bagi sejarah, ilmu pengetahuan, pendidikan, agama, dan kebudayaan

5PT. Kirana Pratiwi, L, N Sutjipta, dan IG. Setiawan AP, "Pariwisata Kerakyatan (Community Based Tourism) Dan Pengaruhnya Pada Kesejahteraan Petani Di Desa Budaya Kertalangu Kota Denpasar", Jurnal Manajemen Agribisnis (Journa(Placeholder1)l Of Agribusiness Management), Vol. 5 No. 1, Mei 2017, hlm. 1. <https://doi.org/10.24843/JMA.2017.v05.101.p01>.

"Dewa Gede Yadhu Basudewa, "Cagar Budaya Kota Denpasar", Pokok-Pokok Pikiran Kebudayaan DaerahDenpasar, 2018, hlm. 1. 
yang dapat dimanfaatkan untuk mewujudkan kesejahteraan. ${ }^{7}$ Harapan besar berada pada pundak Perda Cagar Budaya Kota Denpasar, baik dari sisi keefektifan dalam pengaturannya maupun dalam implementasi dari Perda Cagar Budaya Kota Denpasar tersebut. Keberadaan kebijakan yang telah ada terkait pelestarian cagar budaya di Kota Denpasar tentunya perlu dikaji efektivitasnya sampai saat ini sehingga dapat mengantisipasi dinamika tantangan dan ancaman terhadap warisan budaya dan lingkungan. Dalam hal ini, temuan tentang efektivitas Perda Cagar Budaya Kota Denpasar dan rumusan strategi yang dapat ditempuh untuk mencapai efektivitas Perda tersebut menjadi kajian, sekaligus rujukan, baru yang tidak terdapat dalam penelitian-penelitian terdahulu.

\section{Rumusan Masalah}

Permasalahan yang dapat dirumuskan dalam penelitian ini, yaitu: pertama, bagaimana efektivitas Perda Cagar Budaya Kota Denpasar? Kedua, bagaimana strategi yang dapat ditempuh untuk mencapai efektivitas Perda Cagar Budaya Kota Denpasar.

\section{Tujuan Penelitian}

Tujuan penelitian ini, antara lain: pertama, untuk mengetahui dan menganalisis efektivitas Perda Cagar Budaya Kota Denpasar; kedua, untuk mengetahui dan menganalisis strategi yang dapat ditempuh untuk mencapai efektifnya Perda Cagar Budaya Kota Denpasar.

\section{Metode Penelitian}

Jenis penelitian ini tergolong jenis penelitian sosio-legal. Data yang dianalisis berasal dari data primer bersumber dari data wawancara di lapangan dan data sekunder bersumber dari bahan hukum primer dan bahan hukum sekunder terkait dengan perlindungan dan pengelolaan cagar budaya di Kota Denpasar. Wawancara dilakukan dengan menggunakan bantuan googleform yang disebar di empat kecamatan yang ada di Kota Denpasar, yakni Kecamatan Denpasar Utara, Denpasar Timur, Denpasar Selatan, dan Denpasar Barat. Penyebaran kuisioner dilakukan oleh delapan orang petugas lapangan mulai 1

${ }^{7}$ Hafidz Putra Arifin, "Politik Hukum Perlindungan Cagar Budaya Di Indonesia", Dialogia Iuridica: Jurnal Hukum Bisnis Dan Investasi, Vol. 10, No.1 November 2018, hlm. 65. <https://doi.org/10.28932/di.v10i1.1034>. 
Mei 2018 sampai tanggal 30 Juli 2018 dan dilanjutkan dengan penyebaran kuisioner tambahan pada tanggal 23 Juli 2019. Responden berjumlah enam puluh empat orang di enam belas lokasi sample yang diambil secara pusposivesampling. Wawancara dilakukan terhadap para pengurus adat sebagai pengelola cagar budaya, pemerintah desa lokasi cagar budaya berada, aparatur pemerintah Kota Denpasar yang memiliki tugas dalam bidang cagar budaya, masyarakat yang berdekatan dengan lokasi cagar budaya berada dan pemuka agama tempat lokasi cagar budaya berada. Selain itu, digunakan juga pendekatan perundang-undangan dan pendekatan konseptual. Data yang didapat kemudian dianalisis secara kualitatif dengan metode deduktif-induktif secara bersamaan.

\section{Hasil Penelitian dan Pembahasan}

\section{Perlindungan Hukum terhadap Cagar Budaya}

Keberadaan cagar budaya di Indonesia secara umum telah mendapat pengaturan dan perlindungan secara berjenjang. Konstitusi Indonesia, UndangUndang Dasar Negara Republik Indonesia Tahun 1945, khususnya Pasal 32 ayat (1) mengamanatkan "Negara memajukan kebudayaan nasional Indonesia di tengah peradaban dunia dengan menjamin kebebasan masyarakat dalam memelihara dan mengembangkan nilai-nilai budayanya." Konstitusi Indonesia tersebut mengandung norma konstitusionalyang mewajibkan pemerintah untuk melindungi dan melestarikan semua benda budaya, manifestasi budaya bangsa, sebagai warisan budaya. Pengaturan tentang pemajuan kebudayaan dalam konstitusi tersebut merupakan bentuk perlindungan warisan budaya bangsa yang berorientasi pada pelestarian identitas Indonesia serta bertujuan untuk memajukan kesejahteraan sosial. ${ }^{8}$ Perlindungan hukum bagi budaya adalah penting karena Indonesia memiliki keragaman budaya yang menjadi sangat berharga. ${ }^{9}$

Pengaturan cagar budaya selanjutnya secara nasional tunduk pada ketentuan Undang-Undang Nomor 11 Tahun 2010 tentang Cagar Budaya.

${ }^{8}$ Ibid.

${ }^{9}$ Dyah Permata Budi Asri, "Perlindungan Hukum Terhadap Kebudayaan Melalui World Heritage Centre Unesco", Jurnal Hukum Ius Quia Iustum, Vol. 25 No. 2, Mei 2018, hlm. 256. <https://doi.org/10.20885/iustum.vol25.iss2.art3>. 
Undang-undang ini merupakan landasan legislasi dalam perlindungan dan pengelolaan cagar budaya di Indonesia. Perlindungan cagar budaya di Indonesia kemudian dikuatkan lagi melalui Undang-Undang Nomor 5 Tahun 2017 tentang Pemajuan Kebudayaan yang menjadi dasar pijakan menuju Kota Budaya bagi Kota Denpasar. Undang-undang tersebut membangun harapan tentang pentingnya arti modal budaya untuk masa depan bangsa. Pemerintah Provinsi Bali dan Kota Denpasar telah mengeluarkan beberapa kebijakan tentang perlindungan warisan budaya dan alam di Kota Denpasar guna mengantisipasi tantangan dan ancaman bagi cagar budaya di era globalisasi ini.

Kota Denpasar telah memiliki Peraturan Daerah Kota Denpasar Nomor 12 Tahun 2015 tentang Pengelolaan Cagar Budayasebagai produk hukum daerah yang secara khusus mengatur tentang perlindungan dan pengelolaan cagar budaya yakni Perda Cagar Budaya Kota Denpasar. Perda Cagar Budaya Kota Denpasar hadir selain menguatkan aturan dalam konstitusi dan produk legislasi nasional yang telah disebutkan di atas, secara lokal juga menguatkan keberadaan Peraturan WaliKota Denpasar Nomor 25 Tahun 2010 tentang Persyaratan Arsitektur Bangunan Gedung di Kota Denpasar. Terbitnya Peraturan Wali Kota Denpasar tentang Persyaratan Arsitektur Bangunan Gedung tersebut didasari atas pertimbangan dalam penyelenggaraan bangunan gedung di Kota Denpasar agar memiliki identitas sebagai kota yang berwawasan budaya serta memiliki standardisasi sebagai pedoman bagi pelaksana pembangunan guna menampilkan wujud arsitektur bangunan gedung yang sesuai dengan perkembangan arsitektur tradisional Bali pada masa lalu, masa kini dan masa yang akan datang di Kota Denpasar. Serta, Peraturan Daerah Kota Denpasar Nomor 5 Tahun 2015 tentang Bangunan Gedung dalam pertimbangan terbitnya aturan tersebut antara lain dalam menyelenggarakan bangunan gedung harus dilaksanakan secara tertib, sesuai dengan fungsinya, dan memenuhi persyaratan administratif dan teknis bangunan gedung agar menjamin keselamatan penghuni dan lingkungannya serta harus dapat memberikan keamanan dan kenyaman bagi masyarakat dan lingkungannya. Perda Cagar Budaya Kota Denpasar inilah yang perlu dikaji efektivitasnya sebagai aturan hukum yang bekerja di masyarakat. 
Cagar budaya merupakan kekayaan budaya Bangsa Indonesia. Cagar budaya penting artinya bagi pemahaman dan pengembangan sejarah, ilmu pengetahuan, dan kebudayaan. Benda cagar budaya perlu dilindungi dan dilestarikan demi pemupukan kesadaran jati diri dan kepentingan nasional. ${ }^{10}$ Hukum dapat berkerja dengan baik karena adanya peranan hukum dalam mengubah dan mengarahkan perilaku atau pola-pola tingkah laku pemegang peran, dalam hal ini adalah warga masyarakat. ${ }^{11}$ Bekerjanya hukum di masyarakat ${ }^{12}$ dapat menuju ketertiban hukum.

\section{Efektivitas Hukum Pelestarian Bangunan dan Lingkungan Cagar Budaya di Kota Denpasar}

Efektivitas hukum dapat diartikan sebagai kemampuan hukum untuk menciptakan atau melahirkan kesadaran atau situasi seperti yang dikehendaki atau diharapkan oleh hukum dalam kenyataannya. Hukum tidak hanya berfungsi sebagai kontrol sosial, tetapi dapat juga menjalankan fungsi perekayasaan sosial. ${ }^{13}$ Efektivitas hukum berkaitan langsung dengan keberadaan sistem hukum. ${ }^{14}$ Sistem hukum terdiri dari tiga komponen yaitu: 1) struktur hukum, terdiri dari aparat penegak hukum yang terkait dengan perlindungan dan pengelolaan cagar budaya, 2) substansi hukum, terkait dengan peraturan perundang-undangan yang terkait dengan perlindungan dan pengelolaan cagar budaya; dan 3) budaya hukum masyarakat, yang mengarah ke kesadaran hukum masyarakat, yang dapat dilihat pada perilaku masyarakat sehari-hariuntuk mentaati undangundang atau rambu-rambu hukum yang telah ditetapkan yang berlaku bagi semua subjek hukum dalam kehidupan berbangsa dan bernegara. ${ }^{15}$

\footnotetext{
${ }^{10}$ Ratna Herawati, "Implementasi Undang-Undang Nomor 11 Tahun 2010 Terhadap Pelestarian Benda Cagar Budaya Di Kecamatan Ambarawa Kabupaten Semarang", Hukum Dan Masyarakat Madani, Vol. 6 No. 1, Januari 2016, hlm. 59. <https://doi.org/10.26623/humani.v6i1.854>.

11Suteki, "Implikasi Kebijakan Formulasi Penggunaan Alokasi Dana Bagi Hasil Cukai Tembakau Terhadap Program Pembinaan Lingkungan Sosial", Law Reform, Vol. 13 No. 2, September 2017, hlm. 259. $<$ https://doi.org/10.14710/lr.v13i2.16160>.

${ }^{12}$ Zulkarnain Hasibuan, "Kesadaran Hukum Dan Ketaatan Hukum Masyarakat Dewasa Ini", Publik, Vol.1, No. 1, Maret 2014, hlm. 78.

${ }^{13}$ Winarno Yudho dan Heri Tjandrasari, "Efektivitas Hukum Dalam Masyarakat", Jurnal Hukum \& Pembangunan, Vol. 17 No. 1, Februari 2017, hlm. 57. <Https://Doi.Org/10.21143/Jhp.Vol17.No1.1227>.

${ }^{14} \mathrm{~S}$ Awaluddin dan E I I Ambon, "Pendidikan Dan Instrumen Hukumnya Dalam Pembangunan Budaya Hukum", TAHKIM, Vol. 15 No. 2, Desember 2020, hlm. 125.

${ }^{15}$ Ellya Rosana, "Kepatuhan Hukum Sebagai Kesadaran Hukum Masyarakat", Jurnal Tapis: Jurnal Teropong Aspirasi Politik Islam, Vo. 10 No. 1, Juni 2014, hlm. 1. <https://doi.org/10.24042/TPS.V10I1.1600>.
} 
Data lapangan menunjukkan bahwa peran dari aparatur negara/daerah masih belum maksimal dalam pengelolaan cagar budaya di Kota Denpasar dalam mendukung efektivitas Perda Cagar Budaya Kota Denpasar. Hal ini dapat dilihat dari hasil quisioner menyangkut keterlibatan aparatur negara/daerah dalam pengelolaan cagar budaya di Kota Denpasar. Dari $16^{16}$ lokasi cagar budaya yang digunakan sebagai sample, sebanyak $67 \%$ responden menjawab tidak setuju dengan pernyataan bahwa keterlibatan peran aparatur negara/daerah sudah maksimal dalam pengelolaan cagar budaya, 15\% menjawab sangat tidak setuju, dan $18 \%$ menjawab setuju.

Upaya pelestarian yang dilakukan haruslah berdampak pada meningkatnya kesadaran masyarakat terhadap pentingnya keberadaan bangunan dan benda cagar budaya sehingga masyarakatlah yang lebih berperan serta nanti, sedangkan pemerintah hanya mengayomi dan mengawasi sehingga tidak ke luar dari koridor hukum yang berlaku. ${ }^{17}$ Budaya hukum masyarakat merupakan bagian dari sistem hukum. Budaya hukum masyarakat tidak hanya tercermin oleh perilaku pejabat (eksekutif, legislatif, maupun yudikatif), tetapi juga perilaku masyarakat. Budaya hukum masyarakat memberikan warna dan nuasa kepada struktur hukum dan substansi hukum. ${ }^{18}$ Mengenai efektivitas kebijakan Perda Cagar Budaya Kota Denpasar, jika dikaji dari isi atau substansinya, dapat digambarkan dalam tabel sebagai berikut.

Tabel 1.

Efektivitas Kebijakan Cagar Budaya Kota Denpasar Secara Substansi

\begin{tabular}{|c|c|c|}
\hline No & Ketentuan Pasal & Analisis \\
\hline 1 & $\begin{array}{l}\text { Bab III Tugas dan Wewenang } \\
\text { Pasal } 6 \text { huruf a sampai } \\
\text { dengan huruf } i\end{array}$ & $\begin{array}{l}\text { Mengatur tugas Pemerintah Kota Denpasar } \\
\text { dalam upaya pengelolaan Cagar Budaya. } \\
\text { Belum efektif dalam pelaksanaannya karena } \\
\text { membutuhkan dukungan existing lainnya }\end{array}$ \\
\hline
\end{tabular}

${ }^{16}$ Lokasi penelitian tersebut antara lain, 1) Pura Dalem Puancak, 2) Pura Desa dan Puseh Peguyangan, 3) Pura Bale Agung Intaran, 4) Pura Kembar Madura, 5) Pura Maospahit, 6) Pura Desa Intaran Sanur, 7) Pura Dadya Pasek Gelgel Kesiman, 8) Pura Luhur Catur Kanda Pat Sari, 9) Pura Desa dan Puseh Padangsambian, 10) Pura Dalem Khayangan Desa Padangsambian, 11) Pura Desa dan Puseh Kesiman, 12) Pura Pengerebongan Kesiman, 13) Pura Dalem Penatih, 14) Hotel Inna Bali, 15) Puri Satria, dan 16) Puri Kesiman.

${ }^{17}$ Volare Amanda Irastari dan Rimadewi Suprihardjo, "Pelestarian Kawasan Cagar Budaya Berbasis Partisipasi Masyarakat ( Studi Kasus: Kawasan Cagar Budaya Bubutan , Surabaya)", Jurnal Teknik ITS, Vol 1 No.1, September 2012, hlm. 61.

${ }^{18}$ Abdul Halim Barkatullah, "Budaya Hukum Masyarakat Dalam Persfektif Sistem Hukum, Jurnal Refleksi Hukum, Vol. 13 No.1, Februari 2012, hlm.1. 


\begin{tabular}{|c|c|c|}
\hline & & $\begin{array}{l}\text { dalam artian tugas Pemerintah Kota } \\
\text { Denpasar dalam upaya pengelolaan cagar } \\
\text { budaya harus mendapat dukungan dari } \\
\text { masyarakat yang tinggal di sekitar lokasi } \\
\text { cagar budaya, maupun sebagai pengelola } \\
\text { cagar budaya. Dukungan pemerintah desa } \\
\text { dinas maupun desa adat juga penting untuk } \\
\text { dapat mendukung tugas pemerintah } \\
\text { tersebut. Aturan yang jelas serta dukungan } \\
\text { tim pelaksana kegiatan juga dibutuhkan } \\
\text { dalam pengelolaan cagar budaya. }\end{array}$ \\
\hline 2 & $\begin{array}{l}\text { Pasal } 7 \text { ayat (1) huruf a } \\
\text { sampai huruf } n\end{array}$ & $\begin{array}{l}\text { Mengatur Wewenang Pemerintah Kota } \\
\text { dalam Pengelolaan Cagar Budaya } \\
\text { Belum efektif dalam pelaksanaannya karena } \\
\text { membutuhkan dukungan existing lainnya. } \\
\text { Wewenang Pemerintah Kota Denpasar } \\
\text { dapat berjalan secara efektif jika didukung } \\
\text { oleh aturan pelaksanaan kegiatan yang jelas, } \\
\text { kemudian kesadaran hukum masyarakat } \\
\text { yang baik serta dukungan dari pemerintah } \\
\text { desa dinas dan desa adat tempat dimana } \\
\text { lokasi cagar budaya berada. }\end{array}$ \\
\hline 3 & $\begin{array}{l}\text { Bab IV Kriteria Cagar Budaya } \\
\text { Pasal } 8\end{array}$ & $\begin{array}{l}\text { Kriteria Benda, Bangunan, struktur yang } \\
\text { tergolong Benda Cagar Budaya } \\
\text { Belum efektif dalam pelaksanaannya karena } \\
\text { membutuhkan dukungan existing lainnya. } \\
\text { Dukungan existing lainnya yang dimaksud } \\
\text { disini adalah adanya dukungan dari sisi } \\
\text { norma hukum pelaksana yang jelas, adanya } \\
\text { peran pengelola cagar budaya yang } \\
\text { maksimal baik secara kedinasan maupun } \\
\text { adat serta didukung oleh kesadaran hukum } \\
\text { masyarakat yang baik. }\end{array}$ \\
\hline 4 & $\begin{array}{l}\text { Bab V Registrasi } \\
\text { Budaya } \\
\text { Pasal 12 }\end{array}$ & $\begin{array}{l}\text { Tata Cara Pendaftaran Cagar Budaya } \\
\text { Kata 'dapat' mengandung ketidakpastian } \\
\text { Belum efektif dalam pelaksanaannya karena } \\
\text { membutuhkan dukungan existing lainnya. } \\
\text { Proses pendaftaran cagar budaya perlu } \\
\text { didukung norma hukum pelaksana yang } \\
\text { jelas, kemudian dukungan yang baik dari } \\
\text { pemerintah desa dinas dan desa adat tempat } \\
\text { lokasi cagar budaya berada berserta } \\
\text { kesadaran hukum masyarakat yang baik. } \\
\text { Sampai saat ini pendaftaran baik individu } \\
\text { maupun adat masih kurang. Sampai saat }\end{array}$ \\
\hline
\end{tabular}


5 Pasal 13

6 Pasal 14

7 Pasal 15

8 Pasal 17

9 Pasal 20 ini (Tahun 2019) belum ada pendaftaran yang dilakukan secara individu maupun adat, pendaftaran cagar budaya dilakukan secara sistematik oleh Dinas Kebudayaan Kota Denpasar.

Pengkajian Cagar Budaya

Keberadaan "Tim Ahli Cagar Budaya" saat ini telah dibentuk berdasarkan Surat Keputusan Walikota Denpasar tanggal 17 Desember 2018.

Penetapan Cagar Budaya Dilakukan dari Hasil Pertimbangan Tim Ahli Cagar Budaya.

Keberadaan Tim Ahli Cagar Budayasaat ini telah dibentuk berdasarkan Surat Keputusan Walikota Denpasar tanggal 17 Desember 2018. Namun, Peraturan Walikota tentang pemberian kompensasi belum ada, sehingga hal ini belum efektif memerlukan dukungan dari Pemerintah serta stakeholder terkait untuk menyusun pedoman pemberian kompensasi keberadaan cagar budaya di suatu lokasi.

Pencatatan Cagar Budaya

Pencatatan cagar budaya yang diusulkan secara individu maupun dari pengelola cagar budaya belum berjalan secara maksimal, hal ini dapat dilihat sampai saat ini hanya baru satu Penetapan Prasasti Blanjong sebagai Cagar Budaya Peringkat Kota Denpasar, melalui Surat Keputusan Walikota Denpasar Nomor 188.45/825/HK/2019 tanggal 15 April 2019. Pengalihan Kepemilikan Cagar Budaya.

Pengalihan kepemilikan cagar budaya memerlukan aturan pelaksana dalam bentuk Peraturan Walikota karena diamatkan serta belum diatur secara rinci dan secara jelas dalam bunyi pasal 17 .

Perlu Peraturan Walikota tentang pemberian kompensasi dan insentif cagar budaya. Pemberian kompensasi dan insentif bagi pengelola cagar budaya belum secara jelas dan rinci di atur dalam pasal 20 Perda Cagar Budaya Kota Denpasar, dan diperlukan peraturan pelaksana untuk itu. 


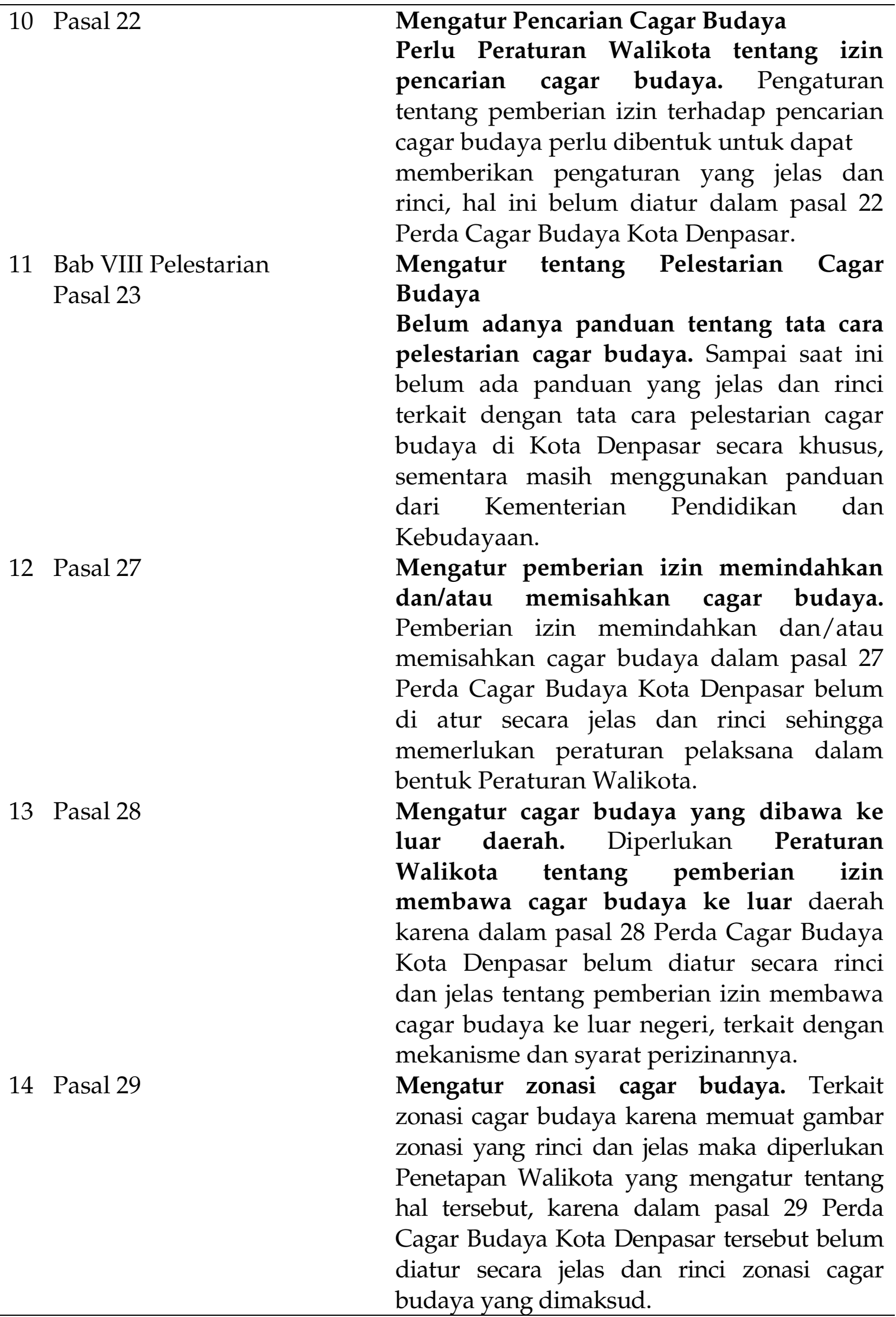




\begin{tabular}{ll}
\hline 15 Pasal 30 & Mengatur Pemeliharaan cagar budaya. \\
& Pasal 30 Perda Cagar Budaya Kota \\
& Denpasar belum mengatur secara jelas dan \\
& rinci terkait mekanisme dan syarat \\
& pemeliharaan cagar budaya sehingga \\
memerlukan peraturan pelaksana dalam & bentuk Peraturan Walikota Denpasar.
\end{tabular}

16 Pasal 31

17 Pasal 39

18 Bab XII

Pembinaan dan Pengawasan

Pasal 41
Mengatur Pemugaran Cagar Budaya. Pasal 31 Perda Cagar Budaya Kota Denpasar belum mengatur secara jelas dan rinci terkait dengan mekanisme da syarat pemugaran cagar budaya di Kota Denpasar, sehingga memerlukan pengaturan yang lebih jelas dan rinci dalam Peraturan Walikota Denpasar sebagai peraturan pelaksananya.

Mengatur Peran Serta Masyarakat dalam pengelolaan cagar budaya.

Pasal 39 Perda Cagar Budaya Kota

Denpasar belum mengatur secara jelas dan rinci terkait peran serta masyarakat baik dari sisi bentuk peran serta masyarakat dan mekanismenya dalam pengelolaan cagar budaya di Kota Denpasar, sehingga memelukan peraturan pelaksana untuk mengatur hal tersebut dalam bentuk Peraturan Walikota Denpasar.

Mengatur pembinaan dan pengawasan cagar budaya

Sampai saat ini belum berjalan maksimal karena belum dibentuk aturan terkait penetapan Tim Pembina dan Pengawas cagar budaya yang memberikan arahan terkait dengan tugas dan wewenangnya dalam pelestarian cagar budaya di Kota Denpasar.

Secara umum, Pemerintah Kota Denpasar telah memiliki usaha dalam bidang legislasi dengan menerbitkan Perda Cagar Budaya Kota Denpasar, sesuai dengan uraian secara singkat di atas, namun Peraturan Daerah tersebut belum cukup efektif secara substansi dalam pelestarian cagar budaya. Buktinya, terdapat beberapa ketentuan yang memerlukan Peraturan Walikota lebih lanjut sebagai pelaksana Perda tersebut, sesuai dengan arahan pasal-pasal dalam Perda Cagar Budaya Kota Denpasar. Legislasi yang dimaksud di atas tentunya berupa 
peraturan daerah yang berpedoman pada asas-asas umum pemerintahan yang baik. ${ }^{19}$

Data lapangan selanjutnya menunjukkan bahwa kesadaran masyarakat tentang keberadaan kebijakan Perda Cagar Budaya Kota Denpasar masih belum efektif berjalan. Ini dapat dianalisis dari hasil kuisioner menyangkut keterlibatan dari kesadaran masyarakat dalam pengelolaan cagar budaya di Kota Denpasar. Dari 16 (enam belas) ${ }^{20}$ lokasi cagar budaya yang digunakan sample, sebanyak $60 \%$ responden menjawab tidak setuju bahwa kesadaran masyarakat dalam pengelolaan cagar budaya sudah tinggi, 14\% menjawab sangat tidak setuju, 24\% menjawab setuju, dan $2 \%$ menjawab sangat setuju.

Kesadaran hukum, baik dari masyarakat maupun pemerintah, berpengaruh terhadap efektivitas Perda Cagar Budaya Kota Denpasar. ${ }^{21}$ Faktor kesadaran hukum dan ketaatan hukum ini mempunyai peran penting dalam perkembangan hukum.Artinya, semakin lemah tingkat kesadaran hukum masyarakat, semakin lemah pula ketatan hukumnya, sebaliknya, semakin kuat kesadaran hukumnya, semakin kuat pula faktor ketaatan hukum. Kesadaran hukum masyarakat yang pada gilirannya menciptakan suasana penegakan hukum yang baik, yang dapat memberikan rasa keadilan, menciptakan kepastian hukum dalam masyarakatdan memberikan kemanfaatan bagi anggota masyarakat. ${ }^{22}$

Terdapat pula faktor pendukung dan penghambat efektivitas implementasi kebijakan pelestarian bangunan dan lingkungan cagar budaya di Kota Denpasar. Faktor pendukung implementasi kebijakan pelestarian bangunan dan lingkungan cagar budaya di Kota Denpasar, antara lain: telah adanya branding Denpasar berwawasan Kota budaya, Kota Denpasar telah memiliki Dewan Kota Pusaka, dan telah memiliki kebijakan tentang pelestarian cagar budaya di Kota Denpasar. Berdasarkan analisis dari kuisioner yang disebar dan kemudian dari analisis tabel

\footnotetext{
${ }^{19}$ Eny Kusdarini, " Asas-Asas Umum Pemerintahan Yang Baik Pada Produk Hukum Perizinan Investasi Pemerintah Daerah", Jurnal Ius Quia Iustum, Vol. 24 No. 4, Juni 2016, hlm. 663. $<$ https://doi.org/10.20885/iustum.vol24.iss4.art8>.

${ }^{20}$ Lokasi penelitian tersebut antara lain, 1) Pura Dalem Puancak, 2) Pura Desa dan Puseh Peguyangan, 3) Pura Bale Agung Intaran, 4) Pura Kembar Madura, 5) Pura Maospahit, 6) Pura Desa Intaran Sanur, 7) Pura Dadya Pasek Gelgel Kesiman, 8) Pura Luhur Catur Kanda Pat Sari, 9) Pura Desa dan Puseh Padangsambian, 10) Pura Dalem Khayangan Desa Padangsambian, 11) Pura Desa dan Puseh Kesiman, 12) Pura Pengerebongan Kesiman, 13) Pura Dalem Penatih, 14) Hotel Inna Bali, 15) Puri Satria, dan 16) Puri Kesiman.

${ }^{21}$ Rosana, Loc. it.

${ }^{22}$ Hasibuan, Loc. it.
} 
SWOT didapatkan data terkait faktor penghambat efektifitas implementasi kebijakan pelestarian bangunan dan lingkungan cagar budaya di Kota Denpasar, antara lain, pertama, belum optimalnya proses penyampaian komunikasi karena pemerintah belum melakukan sosialisasi secara rutin, seiring dengan perubahan sosial dan budaya dari masyarakat tentu pemerintah harus memberikan informasi-informasi yang terbaru yang berhubungan dengan bangunan cagar budaya. Kedua, sumber daya manusia. Sumber daya manusia yang diperlukan adalah sumber daya manusia yang mempunyai keahlian dan pengetahuan yang luas tentang peraturan daerah agar ketentuan-ketetntuan di dalam Perda sesuai dengan harapan pemerintah sebagai pembuat kebijakan dan dari pihak masyarakat agar masyarakat yang berhubungan langsung dengan kebijakan pemerintah tersebut tidak bertolak belakang. Ketiga, disposisi. Dalam implementasi Perda Cagar Budaya Kota Denpasar, sikap aparatur Dinas Kebudayaan dalam melaksanakan kebijakan belum cukup baik. Keempat, aparatur harus bersikap positif terhadap kebijakan yang dibuat mengenai pengelolaan bangunan cagar budaya. Aparatur Dinas Kebudayaan dan Tim Ahli Cagar Budaya harus selalu berkordinasi dan bekerjasama dengan Lembaga Swadaya Masyarakat, termasuk masyarakat di dalam pelestarian bangunan cagar budaya, dan struktur birokrasi (struktur organisasi dalam pelaksanaan kebijakan Perda Cagar Budaya Kota Denpasar belum memilik standar operasional prosedur (SOP) dan fragmentasi atau penyebaran tanggung jawab).

Berdasarkan metode analisis kualitatif, selain deskripsi di atas, didapat juga data yang bersumber dari data lapangan berupa isian kuesioner. Kuesioner yang diberikan memuat kekuatan, kelemahan, peluang, dan tantangan terkait efektivitas Perda Cagar Budaya Kota Denpasar yang telah teridentifikasi melalui kajian lapangan. Dengan menggunakan analisis SWOT, terungkap tingkat pengaruh masing-masing unsur sehingga dapat ditentukan strategi terkait implementasi Perda Cagar Budaya Kota Denpasar dengan metode kuadran sebagai berikut. 
Tabel 2.

Analisis SWOT Perda Cagar Budaya Kota Denpasar

\begin{tabular}{|c|c|c|}
\hline & Strength (Kekuatan) (S) & Weakness (Kelemahan) (W) \\
\hline $\begin{array}{l}\text { Opportunities } \\
\text { (Peluang) }(\mathrm{O}) \\
\text { 1. Peluang } \\
\text { pendanaan } \\
\text { selain dari } \\
\text { negara juga dari } \\
\text { pihak swasta } \\
\text { 2. Potensi ekonomi } \\
\text { yang } \\
\text { berkembang } \\
\text { terkait dengan } \\
\text { wisata cagar } \\
\text { budaya } \\
\text { 3. Denpasar } \\
\text { sebagai Ibu Kota } \\
\text { Provinsi, } \\
\text { pendidikan }\end{array}$ & $\begin{array}{l}\text { 1. Berlakunya Perda } \\
\text { Cagar Budaya Kota } \\
\text { Denpasar } \\
\text { 2. Adanya kearifan lokal } \\
\text { tri hita karana yang } \\
\text { dimasukan sebagai } \\
\text { landasan filosofis Perda } \\
\text { Cagar Budaya } \\
\text { 3. Diaturnya peran serta } \\
\text { masyarakat dalam } \\
\text { pengelolaan cagar } \\
\text { budaya } \\
\text { 4. Diaturnya } \\
\text { kelembagaan cagar } \\
\text { budaya, seperti } \\
\text { Museum dan Tim Ahli } \\
\text { Cagar Budaya } \\
\text { 5. RTRW dan Perda Cagar } \\
\text { Budaya saling } \\
\text { mendukung }\end{array}$ & 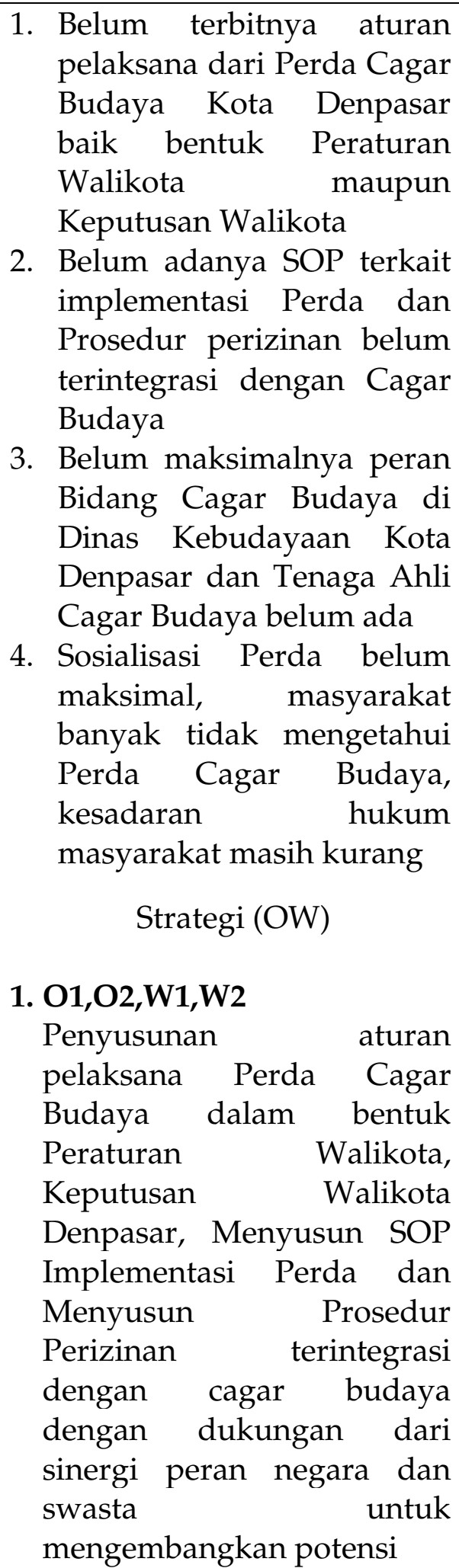 \\
\hline
\end{tabular}




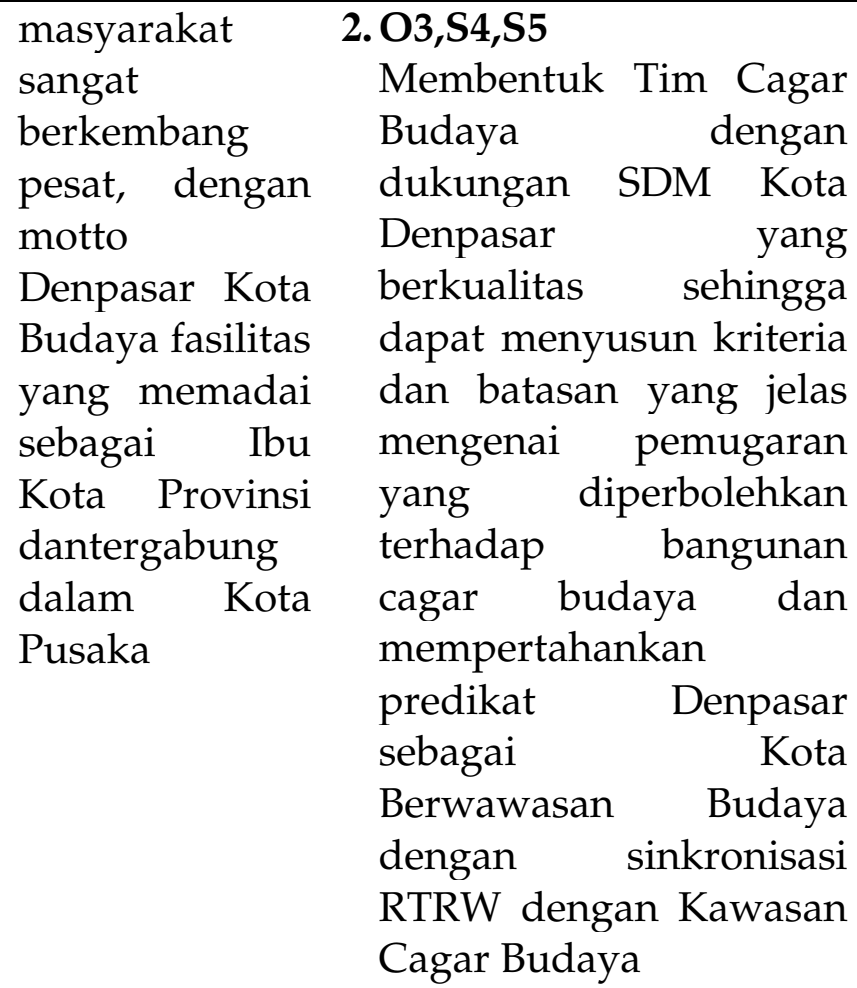

Threats (Tantangan) (T)

1. Peraturan tidak efektif, sanksi kurang tegas

2. Banyaknya Bantuan Sosial dari elit Politik

3. Denpasar sebagai daerah perantauan dengan tipe penduduk yang majemuk

4. Perkembangan masyarakat di era globalisasi dan pencitraan
Strategi (TS)

\section{1. $\mathrm{T} 1, \mathrm{~T} 2, \mathrm{~S} 1, \mathrm{~S} 2, \mathrm{~S} 3$}

Menyempurnakan Perda dan Perwali sebagai bentuk pengendalian terhadap bangunan dan kawasan cagar budaya berbasis kearifan lokal dengan melibatkan peran serta masyarakat, sehingga peraturan lebih efektif dan tegas dan mampu mengendalikan pemugaran cagar budaya dengan dalih bantuan sosial

\section{T3,S4,S5}

Membentuk Tim Cagar Budaya dengan ekonomi berbasis cagar

budaya dengan menyusun panduan kerjasama dan membangun koordinasi antara pemerintah, swasta dan masyarakat, Menyusun kriteria khusus pemugaran cagar budaya

\section{O3,W3,W4}

Memaksimalkan SDM

Kota Denpasar yang berwawasan Budaya dengan tingkat pendidikan secara kuantitas dan kualitas yang baik untuk memaksimalkan peran Bidang Cagar Budaya di Dinas Kebudayaan Kota Denpasar dan Tenaga Ahli Cagar Budaya serta melakukan Sosialisasi Perda sehingga masyarakat banyak mengetahui Perda Cagar Budaya, kesadaran hukum masyarakat meningkat

$$
\text { Strategi (TW) }
$$

\section{T1,T2,W1,W2}

Penyusunan aturan pelaksana Perda Cagar Budaya dalam bentuk Peraturan Walikota, Keputusan Walikota Denpasar, Menyusun SOP Implementasi Perda dan Menyusun Prosedur Perizinan terintegrasi dengan cagar budaya, menyusun panduan kerjasama dan membangun koordinasi antara pemerintah, swasta dan masyarakat, Menyusun kriteria khusus pemugaran cagar budaya sehingga 


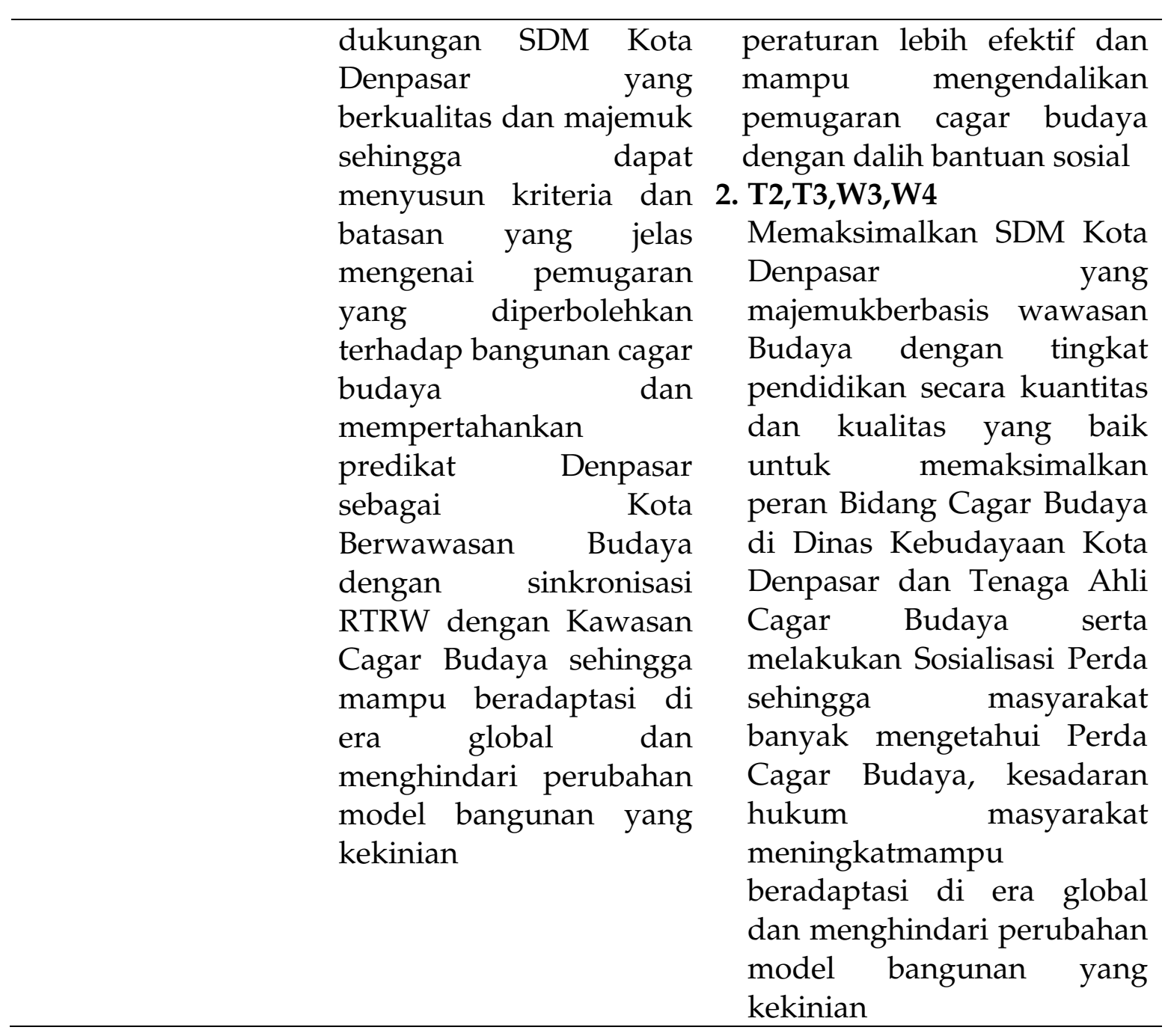

Implikasi singkat dari uraian tabel di atas yakni dengan mengambil peluang dari kelemahan yang ada yang ditemukan baik dari kajian kepustakaan dan kajian terhadap data lapangan terkait efektifitas Perda Cagar Budaya Kota Denpasar untuk kemudian dirumuskan menjadi beberapa strategi untuk mencapai efektifitas Perda Cagar Budaya Kota Denpasar.

\section{Strategi Menuju Efektivitas Perda Cagar Budaya Kota Denpasar}

Berdasarkan ketentuan Pasal 13 Perda Cagar Budaya Kota Denpasar, Tim Ahli Cagar Budaya yang mempunyai tugas untuk mengkaji kelayakan cagar budaya di Kota Denpasar, yang harus dituangkan dalam Keputusan Wali Kota, ternyata diperlukan. Namun, sampai saat ini belum ada Keputusan Wali Kota Denpasar yang mengatur keberadaan Tim Ahli Cagar Budaya di Kota Denpasar. Sehingga, secara yuridis, strategi yang dapat ditempuh agar Perda Cagar Budaya 
Kota Denpasar efektif dengan pembuatan peraturan pelaksana Perda Cagar Budaya Kota Denpasar tersebut. Salah satu strateginya adalah menyusun Keputusan Wali Kota Denpasar tentang Pembentukan Tim Ahli Cagar Budaya Kota Denpasar. Keputusan Walikota sebagai aturan pelaksana harus mampu harmonis dengan hukum yang kedudukannya lebih tinggi. ${ }^{23}$ Harmonisasi antara Peraturan Daerah Kota Denpasar tentang Cagar Budaya dengan Peraturan Pelaksananya (Peraturan Walikota) bertujuan untuk menjamin konsistensi dan keselarasan norma-norma sehingga tidak tumpang tindih antara norma satu dengan norma yang lainnya. ${ }^{24}$

Peraturan Wali Kota Denpasar tentang pemberian kompensasi dan insentif bagi masyarakat yang memiliki dan/atau menguasai cagar budaya yang telah melakukan kewajibannya untuk melindungi cagar budayaperlu juga dibuat. Insentif dan kompensasi di sini diberikan oleh pemerintah ketika masyarakat memiliki suatu peninggalan purbakala. Pemerintah memberikan keringanan dengan tidak mengenakan status pajak kepada masyarakat yang memiliki warisan budaya/cagar budaya berupa situs atau bangunan. ${ }^{25}$

Ketentuan Pasal 31 Perda Cagar Budaya Kota Denpasar terkait dengan pemugaran cagar budaya yang akhir-akhir ini terjadi di beberapa tempat di Kota Denpasar mengharuskan adanya izin Walikota terkait pemugaran bangunan cagar budaya dan struktur cagar budaya serta secara umum diatur dalam Peraturan Wali Kota Kota Denpasar. Sampai saat ini, model izin pemugaran cagar budaya di Kota Denpasar tidak ditemukan sehingga perlu disusun model izin pemugaran cagar budaya di Kota Denpasar. Kedepan, cagar budaya inilah yang menjadi potensi pengembangan ekonomi kreatif berbasis cagar budaya.26Melalui kajian pustaka dan analisi data lapangan, dapat dirumuskan strategi

${ }^{23}$ Ulfia C. Kleden dan Fahril Fanani, "Harmonisasi Ketentuan Peruntukan Bangunan Cagar Budaya Dalam Perspektif Regulasi Di Kawasan Budaya Kotabaru, Kota Yogyakarta-DIY", ReTII, 2015, hlm. 463.

${ }^{24}$ Zaka Firma Aditya dan Muhammad Reza Winata, "Rekonstruksi Hierarki Peraturan PerundangUndangan Di Indonesia", Jurnal Negara Hukum: Membangun Hukum Untuk Keadilan Dan Kesejabteraan, Vol. 9 No. 1 , Juni 2018, hlm. 7. <https://doi.org/10.22212/jnh.v9i1.976>.

${ }^{25}$ Karyamantha Surbakti, "Kebijakan Pengelolaan Warisan Budaya Ditinjau Dari Undang-Undang Nomor 11 Tahun 2010 (Perihal Pemberian Insentif Dan Kompensasi)", Kapata Arkeologi, Vol. 13 No. 2, November 2017, hlm. 141. <https://doi.org/10.24832/kapata.v13i2.397>.

${ }^{26}$ Muhammad Syaifullah dan Basuki Wibowo, "Pemanfaatan Benda Cagar Budaya Sebagai Potensi Pariwisata Dan Ekonomi Kreatif Bagi Masyarakat Sekitar Di Kota Pontianak Kalimantan Barat", Sejarah Dan Budaya: Jurnal Sejarah, Budaya, Dan Pengajarannya, Vol. 10 No. 2, Desember 2016, hlm. 222. $<$ https://doi.org/10.17977/um020v10i22016p222>. 
implementasi Perda Cagar Budaya Kota Denpasar menjadi efektif berdasarkan empat aspek utama, yaitu aspek legal, kelembagaan, fisik, dan pembiayaan. Strategi tersebut tersaji dalam tabel di bawah ini.

Tabel 3.

Strategi Efektifitas Implementasi Perda Cagar Budaya Kota Denpasar

\begin{tabular}{|c|c|c|c|}
\hline $\begin{array}{c}\text { Strategi Aspek } \\
\text { Legal }\end{array}$ & $\begin{array}{l}\text { Strategi Aspek } \\
\text { Kelembagaan }\end{array}$ & $\begin{array}{c}\text { Strategi Aspek } \\
\text { Fisik }\end{array}$ & $\begin{array}{c}\text { Strategi Aspek } \\
\text { Pembiayaan }\end{array}$ \\
\hline $\begin{array}{l}\text { 1. Menyempurnak } \\
\text { an Perda dan } \\
\text { membuat } \\
\text { aturan } \\
\text { pelaksana } \\
\text { terkait } \\
\text { pengendalian } \\
\text { bangunan cagar } \\
\text { budaya } \\
\text { 2. Menyempurnak } \\
\text { an Perda dan } \\
\text { membuat } \\
\text { pelaksana } \\
\text { Perda terkait } \\
\text { perizinan } \\
\text { terintegrasi } \\
\text { cagar budaya } \\
\text { 3. Menyempurnak } \\
\text { an Perda dan } \\
\text { membuat } \\
\text { pelaksana } \\
\text { Perda } \\
\text { penetapan dan } \\
\text { panduan } \\
\text { pemugaran } \\
\text { cagar budaya } \\
\text { 4. Menyusun } \\
\text { panduan } \\
\text { pengelolaan } \\
\text { cagar budaya } \\
\text { antara } \\
\text { pemerintah, } \\
\text { swasta dan } \\
\text { masyarakat } \\
\text { 5. Menyusun SOP } \\
\text { jalur koordinasi } \\
\text { antar Lembaga }\end{array}$ & $\begin{array}{l}\text { 1. Menjalin } \\
\text { kerjasamadeng } \\
\text { an LSM, Media } \\
\text { dan pihak } \\
\text { terkait lainnya } \\
\text { 2. Meningkatkan } \\
\text { peran serta } \\
\text { masyarakat } \\
\text { 3. Menyusun } \\
\text { SOP Tim Ahli } \\
\text { Cagar Budaya } \\
\text { 4. Mensinergikan } \\
\text { kinerja antar } \\
\text { OPD dan } \\
\text { mengimpleme } \\
\text { ntasikan } \\
\text { peraturan } \\
\text { perundang- } \\
\text { undangan } \\
\text { dalam } \\
\text { pengelolaan } \\
\text { cagar budaya } \\
\text { 5. Lebih } \\
\text { mengedepanka } \\
\text { n faktor } \\
\text { pelestarian } \\
\text { budaya } \\
\text { dibandingkan } \\
\text { faktor ekonomi } \\
\text { dan } \\
\text { perkembangan } \\
\text { zaman atau } \\
\text { trend } \\
\text { 6. Memperoleh } \\
\text { proses } \\
\text { birokrasi } \\
\text { dengan }\end{array}$ & $\begin{array}{l}\text { 1. Memprioritask } \\
\text { an bantuan } \\
\text { pemeliharaan } \\
\text { bagi pemilik } \\
\text { bangunan } \\
\text { cagar budaya } \\
\text { yang telah } \\
\text { rusak dan } \\
\text { diprioritaskan } \\
\text { bangunan } \\
\text { yang dimiliki } \\
\text { desa } \\
\text { pakraman } \\
\text { 2. Melaksanakan } \\
\text { revitalisasi } \\
\text { 3. Memberdayak } \\
\text { an bangunan } \\
\text { cagar budaya } \\
\text { 4. Mengendalika } \\
\text { n Bangunan } \\
\text { cagar budaya } \\
\text { 5. Mengkaji } \\
\text { bangunan } \\
\text { yang diduga } \\
\text { cagar budaya }\end{array}$ & $\begin{array}{l}\text { 1. Meningkatkan } \\
\text { anggaran untuk } \\
\text { pengelolaan } \\
\text { cagar budaya } \\
\text { 2. Mempersiapkan } \\
\text { sistem insentif } \\
\text { dan kompensasi } \\
\text { 3. Memberikan } \\
\text { kemudahan } \\
\text { perizinan bagi } \\
\text { pariwisata } \\
\text { berbasis cagar } \\
\text { budaya } \\
\text { berkelanjutan } \\
\text { 4. Memberikan } \\
\text { bantuan } \\
\text { pemeliharaan } \\
\text { cagar budaya } \\
\text { kepada pemilik } \\
\text { cagar budaya }\end{array}$ \\
\hline
\end{tabular}




\begin{tabular}{ll}
\hline terkait yang & dukungan dari \\
berperan dalam & Kepala Daerah \\
pengelolaan & 7. Mengoptimalk \\
cagar budaya & an Tim Ahli \\
6. Membuat Surat & Cagar Budaya \\
Keputusan & dengan Dewan \\
Pembentukan & Kota Pusaka \\
Tim Ahli Cagar & Denpasar \\
Budaya & 8. Meningkatkan \\
& Peran Desa \\
& Adat \\
& 9. Membentuk \\
& Tim Teknis \\
& Pemugaran \\
& Cagar Budaya \\
& Kota Denpasar. \\
\hline
\end{tabular}

Apabila empat aspek tersebut dijalankan, maka kesadaran hukum masyarakat masyarakat dan keteraturan hukum terkait perlindungan dan pengelolaan cagar budaya di Kota Denpasardapat tercapai. Keteraturan hukum yang dimaksud disini adalah adanya harmonisasi hukum antara yang berkedudukan lebih tinggi dengan hukum yang berkedudukan lebih rendah. ${ }^{27}$ Untuk mencapai sasaran perlindungan cagar budaya di Kota Denpasar, strategi di atas kemudian digambarkan dalam bentuk bagan miles stone di bawah ini.

\section{Bagan 1.}

Miles Stone Strategi Pelestarian dan Pengelolaan Cagar Budaya di Kota Denpasar

\section{SASARAN III}

\section{SASARAN II}

\section{SASARAN I}

${ }^{27}$ Yustinus Suhardi Ruman, "Keteraturan Sosial, Norma Dan Hukum", Jurnal Hukum Prioris, Vol. 2 No. 2 , Februari 2013, hlm. 108. 


\section{Sasaran I}

1. Penyusunan aturan pelaksana Perda Cagar Budaya dalam bentuk Peraturan Walikota, Keputusan Walikota Denpasar sebagai turunan Perda Cagar Budaya Kota Denpasar.

2. Membentuk Tim Ahli Cagar Budaya Kota Denpasar secara berkelanjutan.

3. Terbentuknya Tim Teknis Pemugaran cagar budaya.

4. Menyusun SOP Implementasi Perda dan Menyusun Prosedur Perizinan terintegrasi dengan cagar budaya dengan dukungan dari sinergi peran negara dan swasta.

5. Menyusun kriteria khusus pemugaran cagar budaya.

6. Menyusun panduan pengelolaan cagar budaya antara pemerintah, swasta dan masyarakat.

\section{Sasaran II}

1. Memaksimalkan SDM Kota Denpasar yang berwawasan Budaya dengan tingkat pendidikan secara kuantitas dan kualitas yang baik.

2. Meningkatkan anggaran untuk pengelolaan cagar budaya.

3. Sosialisasi Perda sehingga masyarakat banyak mengetahui Perda Cagar Budaya.

\section{Sasaran III}

1. Mengembangkan potensi ekonomi kreatif berbasis cagar budaya dengan menyusun panduan kerjasama dan membangun koordinasi antara pemerintah, swasta dan masyarakat.

2. Memberikan bantuan pemeliharaan (insetif dan disentif) cagar budaya kepada pemilik cagar budaya.

3. Memberikan kemudahan perizinan bagi pariwisata berbasis cagar budaya berkelanjutan.

\section{Penutup}

Terkait dengan efektifitas Perda Cagar Budaya Kota Denpasar secara umum, jika ditinjau dari tiga sisi, yakni peran aparatur daerah, aturan hukum, dan kesadaran hukum masyarakat, Perda Cagar Budaya Kota Denpasar dalam pengaturan dan implementasinya masih belum efektif dalam menunjang pelestarian dan pengelolaan cagar budaya di Kota Denpasar. Walaupun, pada tataran regulasi, Pemerintah Kota Denpasar telah memiliki Perda Cagar Budaya Kota Denpasar sebagai instrumen hukum dalam usaha pelestarian, pengelolaan, dan pemanfaatan cagar budaya di Kota Denpasar. Dengan menggunakan analisis SWOT, berdasarkan bobot dan tingkat pengaruh terhadap implementasi Perda 
Cagar Budaya Kota Denpasar dilapangan dan berdasarkan kajian normatif, ditunjukkan bahwa posisi berada di Kuadran II, yakni dengan meminimalkan kelemahan dan memanfaatkan peluang untuk kemudian merumuskan strategi untuk mencapai efektifitas Perda Cagar Budaya Kota Denpasar.

Terkait dengan strategi untuk mencapai efektifitas Perda Cagar Budaya Kota Denpasar rekomendasi strategi yang dapat disampaikan antara lain, pertama, melakukan penyusunan aturan pelaksana Perda Cagar Budaya Kota Denpasar dalam bentuk Peraturan Wali Kota, Keputusan Wali Kota Denpasar. Kedua, menyusun SOP Implementasi Perda Cagar Budaya Kota Denpasar dan Menyusun Prosedur Perizinan terintegrasi dengan cagar budaya dengan dukungan dari sinergi peran negara dan swasta. Ketiga, mengembangkan potensi ekonomi berbasis cagar budaya dengan menyusun panduan kerjasama dan membangun koordinasi antara pemerintah, swasta dan masyarakat. Keempat, menyusun kriteria khusus pemugaran cagar budaya. Kelima, memaksimalkan SDM Kota Denpasar yang berwawasan Budaya dengan tingkat pendidikan secara kuantitas dan kualitas yang baik untuk memaksimalkan peran Bidang Cagar Budaya di Dinas Kebudayaan Kota Denpasar dan Tenaga Ahli Cagar Budaya. Keenam, melakukan sosialisasi Perda Cagar Budaya untuk meningkatkan pengetahuan dan kesadaran hukum masyarakat.

\section{Daftar Pustaka}

Jurnal

Aditya, Zaka Firma dan Muhammad Reza Winata, "Rekonstruksi Hierarki Peraturan Perundang-Undangan Di Indonesia", Jurnal Negara Hukum: Membangun Hukum Untuk Keadilan Dan Kesejahteraan, Vol. 9 No. 1, Juni 2018.

Arifin, Hafidz Putra, "Politik Hukum Perlindungan Cagar Budaya Di Indonesia", Dialogia Iuridica: Jurnal Hukum Bisnis Dan Investasi, Vol. 10, No.1 November 2018.

Asri, Dyah Permata Budi, "Perlindungan Hukum Terhadap Kebudayaan Melalui World Heritage Centre Unesco", Jurnal Hukum Ius Quia Iustum, Vol. 25 No. 2, Mei 2018.

Awaluddin, $\mathrm{S}$ dan E I I Ambon, "Pendidikan Dan Instrumen Hukumnya Dalam Pembangunan Budaya Hukum", TAHKIM, Vol. 15 No. 2, Desember 2020. 
Barkatullah, Abdul Halim, "Budaya Hukum Masyarakat Dalam Persfektif Sistem Hukum', Jurnal Refleksi Hukum, Vol. 13 No.1, Februari 2012.

Basudewa, Dewa Gede Yadhu, "Cagar Budaya Kota Denpasar", Pokok-Pokok Pikiran Kebudayaan DaerahDenpasar, 2018.

Febianti, "Memperkuat Citra Pariwisata Budaya: Denpasar Sebagai Nominasi Jaringan Kota Kreatif Unesco", Jurnal Master Pariwisata (JUMPA), Vol. 1 No. 2, Juni 2015.

Hasibuan, Zulkarnain, "Kesadaran Hukum Dan Ketaatan Hukum Masyarakat Dewasa Ini", Publik, Vol.1, No. 1, Maret 2014.

Herawati, Ratna, "Implementasi Undang-Undang Nomor 11 Tahun 2010 Terhadap Pelestarian Benda Cagar Budaya Di Kecamatan Ambarawa Kabupaten Semarang", Hukum Dan Masyarakat Madani, Vol. 6 No. 1, Januari 2016.

Irastari, Volare Amanda dan Rimadewi Suprihardjo, "Pelestarian Kawasan Cagar Budaya Berbasis Partisipasi Masyarakat ( Studi Kasus: Kawasan Cagar Budaya Bubutan, Surabaya )", Jurnal Teknik ITS, Vol 1 No.1, September 2012.

Kleden, Ulfia C. dan Fahril Fanani, "Harmonisasi Ketentuan Peruntukan Bangunan Cagar Budaya Dalam Perspektif Regulasi Di Kawasan Budaya Kotabaru, Kota Yogyakarta-DIY", ReTII, 2015.

Kusdarini, Eny, "Asas-Asas Umum Pemerintahan Yang Baik Pada Produk Hukum Perizinan Investasi Pemerintah Daerah", Jurnal Ius Quia Iustum, Vol. 24 No. 4, Juni 2016.

Mulyawan, I Putu Arya, Wirama, Dewa Gede, dan I Dewa Nyoman Badera, "Budaya Tri Hita Karana Sebagai Pemoderasi Pengaruh Prinsip Good Corporate Governance Pada Kinerja Lembaga Perkreditan Desa Di Kota Denpasar", E-Jurnal Ekonomi Dan Bisnis Universitas Udayana, Vol. 6 No. 8, Agustus 2017.

Pratiwi, PT. Kirana, L, N Sutjipta, dan IG. Setiawan AP, "Pariwisata Kerakyatan (Community Based Tourism) Dan Pengaruhnya Pada Kesejahteraan Petani Di Desa Budaya Kertalangu Kota Denpasar", Jurnal Manajemen Agribisnis (Journa(Placeholder1)l Of Agribusiness Management), Vol. 5 No. 1, Mei 2017.

Rosana, Ellya, "Kepatuhan Hukum Sebagai Kesadaran Hukum Masyarakat", Jurnal Tapis: Jurnal Teropong Aspirasi Politik Islam, Vo. 10 No. 1, Juni 2014.

Ruman, Yustinus Suhardi, "Keteraturan Sosial, Norma Dan Hukum", Jurnal Hukum Prioris, Vol. 2 No. 2, Februari 2013.

Surbakti, Karyamantha, "Kebijakan Pengelolaan Warisan Budaya Ditinjau Dari Undang-Undang Nomor 11 Tahun 2010 (Perihal Pemberian Insentif Dan Kompensasi)", Kapata Arkeologi, Vol. 13 No. 2, November 2017. 
Suteki, "Implikasi Kebijakan Formulasi Penggunaan Alokasi Dana Bagi Hasil Cukai Tembakau Terhadap Program Pembinaan Lingkungan Sosial", Law Reform, Vol. 13 No. 2, September 2017.

Syaifullah, Muhammad dan Basuki Wibowo, "Pemanfaatan Benda Cagar Budaya Sebagai Potensi Pariwisata Dan Ekonomi Kreatif Bagi Masyarakat Sekitar Di Kota Pontianak Kalimantan Barat", Sejarah Dan Budaya: Jurnal Sejarah, Budaya, Dan Pengajarannya, Vol. 10 No. 2, Desember 2016.

Udayana, Anak Agung Gde Bagus, "Marginalisasi Ideologi Tri Hita Karana Pada Media Promosi Pariwisata Budaya Di Bali", Mudra Jurnal Seni Budaya, Vol. 32 No. 1, Juni 2017.

Yudho, Winarno dan Heri Tjandrasari, "Efektivitas Hukum Dalam Masyarakat", Jurnal Hukum \& Pembangunan, Vol. 17 No. 1, Februari 2017.

Yusiana, Lury Sevita, "Konsep Interpretasi Guna Melestarikan Tapak Sejarah Di Pecinan Jalan Gajah Mada, Denpasar", Jurnal Arsitektur Lansekap, Vol. 2 No. 2, Oktober 2016.

\section{Peraturan Perundang-Undangan}

Undang-Undang Nomor 11 Tahun 2010 tentang Cagar Budaya, Lembaran Negara Republik Indonesia Tahun 2010 Nomor 130, Tambahan Lembaran Negara RI Nomor 5168

Undang-Undang Nomor 5 Tahun 2017 tentang Pemajuan Kebudayaan, Lembaran Negara Republik Indonesia Tahun 2017 Nomor 104, Tambahan Lembaran Negara RI Nomor 6055

Peraturan Daerah Kota Denpasar Nomor 12 Tahun 2015 tentang Pengelolaan Cagar Budaya, Lembaran Daerah Kota Denpasar Tahun 2015 Nomor 12, Tambahan Lembaran Daerah Kota Denpasar Nomor 12 